\title{
PENGARUH FAKTOR PRIBADI TERHADAP KEPUASAN KONSUMEN MENGGUNAKAN HANDPHONE SAMSUNG DI KOTA PALU
}

\author{
RAZANA \\ SYAMSUL BAHRI DP \\ ANDI INDRIANI \\ Jurusan Manajemen, Fakultas Ekonomi, Universitas Tadulako \\ Email: razanaalamrie0901@gmail.com
}

\begin{abstract}
The purpose of this study is to determine the influence of personal factors on customer satisfaction in using Samsung mobile phone in Palu City. The variables studied are age and stage of life cycle (X1), job (X2), economic circumstances (X3), lifestyle (X4), personality and self-concept (X5), as well as customer satisfaction $(Y)$. Research method is descriptive causal with sample of 60 respondents who selected by accidental side method. Data is analyzed with multiple linear regressions in SPSS software 19. Based on the analysis, the results confirmed that age and stage of life cycle (X1), job $(X 2)$, economic circumstances (X3), lifestyle (X4), personality and self-concept (X5), simultaneously and partially have significant influence on customer satisfaction in using Samsung mobile phone in Palu City.
\end{abstract}

Keywords: Personal Factors and Customer Satisfaction

\begin{abstract}
Abstrak
Tujuan dari penelitian ini adalah untuk mengetahui pengaruh factor pribadi Kepuasan Pelanggan Menggunakan Handphone Samsung di kota Palu. Variabel yang digunakan adalah variabel usia dan tahap siklus hidup (X1), variabel job (X2), variabel keadaan ekonomi (X3), variabel gaya hidup (X4), variabel kepribadian dan self-concept (X5), serta variabel pelanggan kepuasan (Y). Metode yang digunakan adalah metode deskriptif dengan sampel sebanyak 60 responden, dan teknik yang digunakan untuk menentukan sampel adalah metode Accidental Side, yang kemudian akan dianalisis regresi linier berganda pada perangkat lunak SPSS 19. Berdasarkan hasil analisis menunjukkan bahwa variabel umur dan tahap siklus hidup (X1), variabel job (X2), variabel keadaan ekonomi (X3), variabel gaya hidup (X4), variabel kepribadian dan self-concept (X5) secara serempak dan partial berpengaruh signifikan terhadap serta kepuasan pelanggan menggunakan handphone Samsung di Kota Palu.
\end{abstract}

Kata Kunci: Faktor Pribadi dan Kepuasan Pelanggan

\section{PENDAHULUAN}

\section{Latar Belakang Penelitian}

Perkembangan dan kemajuan teknologi yang semakin mengglobal membawa dampak pada dunia usaha.Selalu bersaing dalam hal peningkatan mutu produk barang dan jasa.Salah satu kemajuan teknologi adalah bidang komunikasi yang diciptakan untuk memudahkan sistem komunikasi bagi masyarakat.Komunikasi merupakan hal yang biasa terjadi dalam kehidupan manusia sehari-hari dan menjadi hal yang sangat penting bagi kehidupan kalangan remaja, untuk saling berkomunikasi dengan sesama dan mendapatkan informasi dengan cepat.Pertumbuhan teknologi yang cepat membuat masyarakat mau tak mau harus mengikutinya.Salah satu alat komunikasi yang berkembang dengan cepat adalah handphone.Handphone sendiri merupakan perangkat telekomunikasi elektronik yang mempunyai kemampuan dasar yang sama dengan telepon konvensional saluran tetap, namun dapat dibawa kemana-mana dan tidak perlu disambungkan dengan menggunakan kabel. Perangkat ini mulai populer pada era tahun 2000an dan berkembang pesat hingga kini.

Faktor pribadi ini tercermin pada usia dan tahap siklus hidup, yaitu keadaan yang menggambarkan riwayat manusia sejak awal tahun kehidupannya sampai dengan akhir kehidupannya (Simamora, 2000). Faktor pribadi meliputi usia dan tahap dalam siklus hidup pembeli, pekerjaan dan keadaan 
ekonomi, keperibadian dan konsep diri, serta gaya hidup dan nilai. Karena banyak dari karekteristik ini yang mempunyai dampak sangat langsung terhadap perilaku konsumen, penting bagi pemasar untuk mengikuti mereka secara seksama (Kotler \& Keller, 2009).

\section{Permasalahan Penelitian}

Berdasarkan latar belakang penelitian yang telah dipaparkan sebelumnya, maka secara terinci permasalahan dalam peneitian ini dapat dirumuskan sebagai berikut :

1. Apakah faktor pribadi yang terdiri dari usia dan tahap siklus hidup (X1), pekerjaan (X2), keadaan ekonomi (X3), kepribadian dan konsep diri (X4), serta gaya hiudp (X5), secara serempak berpengaruh signifikan terhadap kepuasan konsumen menggunakan Handphone Samsung Di Kota Palu?

2. Apakah usia dan tahap siklus hidup (X1) secara parsial berpengaruh signifikan terhadap kepuasan konsumen menggunakan Handphone Samsung di Kota Palu?

3. Apakah pekerjaan (X2)secara parsial berpegaruh signifikan terhadap kepuasan konsumen menggunakan Handphone Samsung di Kota Palu?

4. Apakah keadaan ekonomi (X3) secara parsial berpengaruh signifikan terhadap kepuasan konsumen menggunakan Handphone Samsung di Kota Palu?

5. Apakah konsep diri (X4) secara parsial berpengaruh signifikan terhadap kepuasan konsumen menggunakan Handphone Samsung di Kota Palu?

6. Apakah gaya hidup (X5) secara parsial berpengaruh signifikan terhadap kepuasan konsumen menggunakan Handphone Samsung di Kota Palu?

\section{Tujuan Penelitian}

Setiap aktivitas manusia mengarah pada pencapaian tujuan yang optimal, oleh karena itu tujuan yang ingin di cari dari penelitian ini adalah:

1. Untuk mengetahui faktor pribadi yang terdiri dari usia dan tahap siklus hidup, pekerjaan, keadaan ekonomi, gaya hidup serta kepribadian dan konsep diri secara serempak berpengaruh signifikan terhadap kepuasan konsumen menggunakan Handphone Samsung di Kota Palu.

2. Untuk mengetahui pengaruh signifikan usia dan tahap siklus hidup (X1) terhadap kepuasan konsumen menggunakan Handphone Samsung di Kota Palu.

3. Untuk mengetahui pengaruh signifikan pekerjaan (X2) terhadap kepuasan konsumen menggunakan Handphone Samsung di Kota Palu.

4. Untuk mengetahui pengaruh signifikan keadaan ekonomi (X3) terhadap kepuasan konsumen menggunakan Handphone Samsung di Kota Palu.

5. Untuk mengetahui pengaruh konsep diri (X4) terhadap kepuasan konsumen menggunakan Handphone Samsung di Kota Palu.

6. Untuk mengetahui pengaruh signifikan gaya hidup (X5) terhadap kepuasan konsumen menggunakan Handphone Samsung di Kota Palu.

\section{KAJIAN LITERATUR DAN PENGEMBANGAN HIPOTESIS Pengertian Pemasaran}

Pemasaran adalah proses sosial dan manajerial di mana pribadi atau organisasi memperoleh apa yang mereka butuhkan dan inginkan melalui penciptaan dan pertukaran nilai dengan yang lain. Dalam konteks bisnis yang lebih sempit, pemasaran mencakup menciptakan hubungan pertukaran muatan nilai dengan pelanggan yang menguntungkan. Karena itu, kita mendefinisikan pemasaran (marketing) sebagai proses di mana perusahaan menciptakan nilai bagi pelanggan dan menciptakan nilai yang kuat 
dengan pelanggan, dengan tujuan menangkap nilai dari pelanggan sebagai imbalannya (Kotler \& Amstrong, 2008).

\section{Pengertian Perilaku Konsumen}

Menurut Kotler \& Keller, (2009) menyatakan bahwa perilaku konsumen adalah study tentang bagaimana individu, kelompok, dan organisasi memilih, membeli, menggunakan dan bagaimana barang jasa, ide, atau pengalaman untuk memuaskan keinginan dan kebutuhan mereka.

\section{METODE PENELITIAN}

\section{Metode Pengumpulan Data}

Adapun teknik pengumpulan data yang di gunakan dalam penelitian ini terdiri dari:

1. Observasi, yaitu pengumpulan data dengan mengadakan pengamatan secara langsung pada sejumlah fenomena yang terjadi dikalangan masyarakat (konsumen) yang dinilai memberikan implikasi pada kepribadian sehingga memutuskan menggunakan Handphone Samsung.

2. Wawancara, (Interview) yaitu tanya jawab secara langsung kepada responden, dalam hal ini konsumen yang menggunakan Handphone Samsung di Kota Palu

3. Kuesioner, yaitu daftar pertanyaan yang akan diberikan kepada responden, dalam hal ini dalah konsumen menggunakan Handphone Samsung di Kota Palu

\section{Pengujian Instrumen Penelitian \\ Uji Validitas}

Uji Validitas adalah Instrumen yang valid berarti alat ukur yang digunakan untuk mendapat data (mengukur) itu valid. Valid berarti intrumen tersebut dapat digunakan untuk mengukur apa yang seharusnya diukur (Sugiyono, 2014).

\section{Uji Realibilitas}

Uji Reabilitas adalah instrumen yang digunakan untuk mengukur berkali-kali dengan menghasilkan data yang sama (konsisten) itu valid (Sugiyono, 2014).

\section{Uji Asumsi Klasik}

Masalah-masalah dalam pengujian model regresi dalam penelitian ini dapat menggunakan bentuk model pengujian klasik.

\section{Uji Normalitas Data}

Uji normalitas bertujuan untuk mengetahui apakah dalam sebuah model regresi, variabel independen (bebas), variabel dependen (terikat) atau keduanya mempunyai distribusi normal atau tidak.

\section{Uji Multikolinieritas}

Uji multikolinieritas berguna untuk mengetahui apakah pada model regresi yang diajukan telah ditemukan korelasi yang kuat antarvariabel independen. Jika terjadi korelasi yang kuat, terdapat masalah multikoleniaritas yang harus diatasi.

\section{Uji Heterokedastistas}

Salah satu asumsi klasik dalam analisis regresi berganda adalah distribusi probabilitas gangguan tetap untuk seluruh nilai-nilai variabel bebas, yang disebut heterokedastisitas.

\section{Metode Analisis}

Metode ini digunakan untuk memberikan gambaran mengenai pengaruh faktor pribadi (usia, dan tahap siklus hidup, pekerjaan, keadaan ekonomi, kepribadian dan konsep diri, serta gaya hidup) terhadap kepuasan menggunakan Handphone Samsung di Kota Palu. 
Model umum bentuk persamaan alat analisis statistic parametric Regresi Linear Berganda dapat digambarkan sebagai berikut menurut Sugiyono (2013).

$$
\mathrm{Y}=\mathrm{a}+\mathrm{b} 1 \mathrm{X} 1+\mathrm{b} 2 \mathrm{X} 2+\ldots \ldots+\mathrm{bn} \mathrm{Xn}
$$

Dimana :

Y : Variabel dependen;

$\mathrm{X}_{1-} \mathrm{X}_{\mathrm{k}} \quad$ : Variable independen;

a $\quad:$ Konstantan (intercept);

$\mathrm{b}_{1} \mathrm{~b}_{\mathrm{k}} \quad$ : Besaran yang digunakan (koefisien regresi)

Selanjutnya formulasi di atas jika dimaksukkan kedalam variabel penelitian maka dapat diperoleh persamaan regresi berganda sebagai berikut:

\title{
$Y=a+b_{1} X_{1}+b_{2} X_{2}+b_{3} X_{3}+b_{4} X_{4}+b_{5} X_{5}$
}

\author{
Dimana : \\ Y : Kepuasan konsumen membeli Handphone Samsung Galaxy; \\ X1 : Usia dan tahap siklus hidup; \\ X2 : Pekerjaan; \\ X3 : Keadaan Ekonomi; \\ X4 : Gaya hidup; \\ X5 : Kepribadian dan konsep diri; \\ a : Konstanta; \\ b1-b5 : Koefisien Regresi
}

\section{Pengujian Hipotesis Pertama}

Kemudian untuk menguji kebarartian dari koefisien regresi secara serempak digunakan dengan kaidah pengambilan keputusan sebagai berikut sesuai hasil yang didapatkan pada perhitungan statistik menggunakan program SPSS 19 :

1. Jika probabilitas signifikansi F Sig $<\alpha(0,05)$ pada tingkat keperjayaan $95 \%$, terbukti bahwa semua faktor bebas $(\mathrm{X})$ secara serempak berpengaruh signifikan terhadap faktor terikat $(\mathrm{Y})$ dengan kata lain menerima hipotesis alternative (Hi) dan menolak hopotesis mula-mula (Ho).

2. Jika Probabilitas signifikansi F Sig $>\alpha(0,05)$ pada tingkat kepercayaan 95\%, maka terbukti bahwa semua faktor bebas (X) secara serempak berpengaruh tidak signifikan terhadap factor terikat $(\mathrm{Y})$ dengan kata lain menolak hipotesis (Hi) dan menerima hipotesis mula-mula (Ho).

\section{Pengujian Secara Persial untuk Hipotesis Kedua Sampai Enam}

Sedangkan untuk menguji pengaruh dari masing-masing faktor bebas secara persial terhadap faktor terikat (Y) digunakan alat statistik program komputer SPSS 19 dengan kaidah pengambilan keputusan sebagai berikut:

1. Jika probabilitas signifikansi Sig $<\alpha=0,05$ pada tingkat keperjayaan $95 \%$, maka terbukti secara parsial faktor bebas (Xi) berpengaruh secara nyata (signifikan) terhadap faktor terikat (Y) atau dengan kata lain menerima hipotesis alternatif (Hi) dan menolak hopotesis mula-mula (H0).

2. Jika probabilitas signifikansi Sig $>\alpha 0,05$ pada tingkat keperjayaan $95 \%$, maka terbukti secara parsial faktor bebas (Xi) tidak berpengaruh secara nyata (signifikan) terhadap faktor terikat (Y) atau dengan kata lain menolak hopotesis alternative (Hi) dan menerima hipotesis mula-mula. 


\section{HASIL DAN PEMBAHASAN}

\section{Uji Instrumen Penelitian}

Uji instrument penelitian dimaksudkan untuk mendeteksi data penelitian yang sah dan andal. Oleh karena itulah dalam uji instrument penelitian digunakan uji validitas dan uji reliabilitas. Hal ini dapat disajikan pada uraian berikut ini:

\section{Uji Validitas}

Uji Validitas adalah Instrumen yang valid berarti alat ukur yang digunakan untuk mendapat data (mengukur) itu valid. Valid berarti intrumen tersebut dapat digunakan untuk mengukur apa yang seharusnya diukur. (Sugiyono, 2014). Untuk menguji validitas, dapat digunakan pendapat dari ahli (judgment experts). Dalam hal ini setelah instrument dikonstruksi tentang aspek-aspek yang akan diukur dengan berlandaskan teori tertentu, maka selanjutnya dikonsultasikan dengan ahli. Menurut (Sugiyono 2014:178) Suatu instrument itu valid atau tidak, dapat diketahui dengan cara mengkorelasi antara skor butir dengan skor total (Y). Apabila sampel yang digunakan dalam penelitian ini adalah kalau $\mathrm{r}=0.3$. jadi kalau korelasi di bawah 0.30, maka dapat simpulkan bahwa butir instrument tersebut tidak valid, sehingga harus diperbaiki atau dibuang. Adapun hasil uji validitas dari setiap instrument penelitian dapat disajikan melalui Tabel 1 berikut ini:

Tabel 1. Hasil Uji Validitas

\begin{tabular}{lcccc}
\hline Variabel & Pertanyaan & Korelasi & Standar & Keterangan \\
\hline 1. Usia dan Tahap Siklus Hidup (X1) & X1.1 & 0,413 & 0,30 & Valid \\
& X1.2 & 0,395 & 0,30 & Valid \\
& X1.3 & 0,393 & 0,30 & Valid \\
& X1.4 & 0,459 & 0,30 & Valid \\
\hline 2. Pekerjaan (X2) & X2.1 & 0,452 & 0,30 & Valid \\
& X2.2 & 0,451 & 0,30 & Valid \\
& X2.3 & 0,391 & 0,30 & Valid \\
& X2.4 & 0,425 & 0,30 & Valid \\
\hline 3. Kadaan Ekonomi (X3) & X3.1 & 0,503 & 0,30 & Valid \\
& X3.2 & 0,556 & 0,30 & Valid \\
& X3.3 & 0,490 & 0,30 & Valid \\
& X3.4 & 0,363 & 0,30 & Valid \\
\hline 4. Gaya Hidup (X4) & X4.1 & 0,544 & 0,30 & Valid \\
& X4.2 & 0,493 & 0,30 & Valid \\
& X4.3 & 0,565 & 0,30 & Valid \\
& X4.4 & 0,520 & 0,30 & Valid \\
\hline 5. Kepribadian dan Konsep Diri (X5) & X5.1 & 0,455 & 0,30 & Valid \\
& X5.2 & 0,386 & 0,30 & Valid \\
& X5.3 & 0,403 & 0,30 & Valid \\
& X5.4 & 0,446 & 0,30 & Valid \\
\hline 6. Kepuasan Konsumen (Y) & Y1.1 & 0,411 & 0,30 & Valid \\
& Y1.2 & 0,636 & 0,30 & Valid \\
& Y1.3 & 0,509 & 0,30 & Valid \\
& Y1.4 & 0,599 & 0,30 & Valid \\
\hline
\end{tabular}

Berdasarkan Tabel 1 dapat diketahui nilai dari Correct Item Total Correlation > 0,30 sehingga dapat disimpulkan seluruh item pernyataan pada kuesioner adalah valid. 


\section{Uji Reliabilitas}

Uji Reabilitas adalah instrumen yang digunakan untuk mengukur berkali-kali dengan menghasilkan data yang sama (konsisten) itu valid. (Sugiyono, 2014). Pengujian reliabilitas instrumen dapat dilakukan secara eksternal maupun enternal. Secara eksternal pengujian dapat dilakukan dengan testretest (stability), equivalent, dan gabungan keduanya. Secara internal reliabilitas instrumen dapat diuji dengan menganalisis konsistensi butir-butir yang ada pada instrument dengan teknik tertentu. Dalam arti mempunyai ketepatan dan keakuratan mnagkap variabel yang diteliti walaupun dilakukan oada waktu yang berbeda. Untuk menguji tingkat konsistensi hasil yang dicapai oleh sebuah alat ukur, maka dilakukan uji reabilitas dengan cara mengkorelasikan jawaban ganjil dengan genap yang terlebih dahulu di skor.

Untuk menguji realibitasi instrument dapat menggunakan korelasi spearman rank. Menurut (Sugiyono, 2014) Spearman Rank digunakan mencari hubungan atau untuk menguji signifikan hipotesis asosiatif bila masing-masing variabel yang dihubungan berbentuk ordinal, dan sumber data variael tidak harus sama.

Selanjutnya akan disajikan hasil uji reliabilitas dari variabel penelitian yang dapat dilihat melalui Tabel 2 berikut ini:

Tabel 2. Hasil Uji Reliabilitas

\begin{tabular}{clccl}
\hline No. & \multicolumn{1}{c}{$\begin{array}{c}\text { Variabel } \\
\text { Penelitian }\end{array}$} & $\begin{array}{c}\text { Cronbach's } \\
\text { Alpha }\end{array}$ & $\begin{array}{c}\text { Standar } \\
\text { Cronbach's } \\
\text { Alpha }\end{array}$ & Keterangan \\
\hline 1. & Usia dan Tahap Siklus Hidup (X1) & 0,634 & 0,60 & Reliabel \\
2. & Pekerjaan (X2) & 0,648 & 0,60 & Reliabel \\
3. & Keadaan Ekonomi (X3) & 0,931 & 0,60 & Reliabel \\
4. & Gaya Hidup (X4) & 0,729 & 0,60 & Reliabel \\
5. & Kepribadian dan Konsep Diri (X5) & 0,642 & 0,60 & Reliabel \\
4. & Kepuasan Konsumen (Y) & 0,741 & 0,60 & Reliabel \\
\hline
\end{tabular}

Berdasarkan informasi dalam tabel 2 di atas, maka dapat disimpulkan bahwa seluruh variabel penelitian dalam instrumen penelitian (kuesioner) menunjukan nilai konsisten yang tinggi sehingga dinilai realibel dalam fungsi ukurnya. Artinya, instrumen penelitian (kuesioner) dalam fungsi ukurnya memiliki reliabilitas yang tinggi untuk mampu menghasilkan konsistensi pengukuran di dalam menganalisis pengaruh faktor pribadi terhadap kepuasan konsumen membeli Handphone Samsung di Kota Palu.

\section{Identitas Responden}

Deskripsi profil responden merupakan identitas responden yang memberikan interprestasi terhadap obyektivitas dari penelitian mengenai "Pengaruh Faktor Pribadi terhadap Kepuasan Konsumen Membeli Handphone Samsung di Kota Palu". Deskripsi profil responden 60 orang dengan menggunakan teknik accidental sampling.

Deskripsi profil responden dibagi menjadi 5 bagian yakni menurut : Umur responden, jenis pekerjaan, jenis kelamin, dan tingkat pendapatn dan waktu penggunaan Handphone Samsung. Sedangkan deskripsi profil responden bertujuan untuk mengetahui sejauh mana kepuasan pelanggan terhadap Handphone Samsung di Kota Palu. Data-data yang diperoleh diolah dengan menggunakan tabulasi silang sehingga diperoleh gambaran secara menyeluruh dan terperinci jumlah total dari setiap item yang dipertanyakan sehingga akan mudah untuk diinterpretasikan secara kuantitatif. Deskripsi profil responden pada penelitian ini, pada Tabel 3 berikut ini: 
Tabel 3. Identitas Responden

\begin{tabular}{|c|c|c|c|}
\hline \multirow{2}{*}{ Jenis Identitas Responden } & \multirow{2}{*}{ Keterangan } & \multicolumn{2}{|c|}{ Frekuensi } \\
\hline & & Orang & $\%$ \\
\hline \multirow[t]{3}{*}{ 1. Jenis kelamin } & Laki-laki & 29 & 48,33 \\
\hline & Perempuan & 31 & 51,67 \\
\hline & TOT A L & 60 & 100 \\
\hline 2. Waktu Penggunaan Hp & $<1$ Tahun & 13 & 21,67 \\
\hline \multirow[t]{4}{*}{ Samsung } & $1-2$ Tahun & 19 & 31,66 \\
\hline & $3-4$ Tahun & 15 & 25,00 \\
\hline & $>5$ Tahun & 13 & 21,67 \\
\hline & TO T A L & 60 & 100 \\
\hline \multirow[t]{5}{*}{ 3. Usia } & $17-20$ Tahun & 20 & 33,33 \\
\hline & $20-25$ Tahun & 22 & 36,67 \\
\hline & $26-35$ Tahun & 12 & 20,00 \\
\hline & $36-45$ Tahun & 6 & 10,00 \\
\hline & TO T A L & 60 & 100 \\
\hline \multirow[t]{6}{*}{ 4. Pekerjaan } & PNS & 15 & 25,00 \\
\hline & Pegawai Swasta & 24 & 40,00 \\
\hline & Wiraswasta & 13 & 21,67 \\
\hline & Mahasiswa & 22 & 36,67 \\
\hline & Lain-lainnya & 3 & 5,00 \\
\hline & TO T A L & 60 & 100 \\
\hline \multirow[t]{5}{*}{ 5. Pendapatan } & $<1.500 .000$ & 10 & 16,67 \\
\hline & $1.500 .000-3.000 .000$ & 23 & 38,33 \\
\hline & $3.000 .000-5.000 .000$ & 18 & 30,00 \\
\hline & $>5.000 .000$ & 9 & 15,00 \\
\hline & TOT A L & 60 & 100 \\
\hline
\end{tabular}

Berdasarkan hasil penelitian, diketahui bahwa pembeli Handphone Samsung didominasi oleh perempuan dengan jumlah sebanyak 31 responden atau sebesar $51,67 \%$ sedangkan pembeli laki-laki berjumlah 29 responden atau sebesar 48,33\%. Hal tersebut dikarenakan fitur Handphone Samsung sesuai dengan gender, Selanjutnya Profil responden berdasarkan lama pemakaian Handphone Samsung, dimana hasil yang didapatkan pengguna Handphone Samsung lebih banyak menggunakan Handphone Samsung berkisar antara 1 - 2 Tahun yaitu dengan jumlah sebanyak 19 atau 31,66\% sedangkan penggunaan $<1$ Tahun hanya 13 responden atau sebesar $21,67 \%$, hasil yang sama juga terdapat pada penggunaan $>5$ Tahun.

Selanjutnya profil responden berdasarkan usia, dimana pengguna dengan usia 20 - 25 Tahun lebih banyak dengan sebanyak 22 atau 36,67\% sedangkan pengguna dengan Usia 36 - 45 tahun sebanyak 6 Responden atau sebesar $10,00 \%$. Profil berdasarkan identitas responden pekerjaan ini lebih banyak di dominasi sebanyak 24 atau $40,00 \%$ dan yang terendah adalah yang memiliki pekejaan wiraswasta yaitu sebanyak 13 atau sebesar 21,67\%. Dan profil responden terakhir adalah dimana hasil dari penyebaran kuesioner bahwa responden yang memiliki penghasilan $1.500 .000-3.000 .000$ sebanyak 23 atau 38,33\% sedangkan responden yang memiliki penghasilan $>5.000 .000$ hanya dipilih oleh 9 atau $15,00 \%$. 


\section{Analisis Regresi Linier Berganda}

Analisis regresi linier berganda digunakan dalam penelitian ini dengan tujuan untuk membuktikan hipotesis mengenai pengaruh variabel dimensi-dimensi kualitas pelayanan secara parsial maupun secara bersama-sama terhadap kepuasan konsumen. Perhitungan statistik dalam analisis regresi linier berganda yang digunakan dalam penelitian ini adalah dengan menggunakan bantuan program komputer SPSS for Windows versi 19.

Tabel 4. Hasil Analisis Regresi Linier Berganda Coefficients ${ }^{\mathrm{a}}$

\begin{tabular}{|c|c|c|c|c|c|c|c|c|}
\hline \multirow{2}{*}{\multicolumn{2}{|c|}{ Model }} & \multicolumn{7}{|c|}{$\begin{array}{l}\text { Unstandardized Standardized } \\
\text { Coefficients Coefficients }\end{array}$} \\
\hline & & B & Std. Error & Beta & $\mathrm{t}$ & Sig. & Tolerance & VIF \\
\hline \multirow[t]{6}{*}{1} & (Constant) & 4.313 & .612 & & 7.046 & .000 & & \\
\hline & $\mathrm{X} 1$ & .343 & .096 & .422 & 3.581 & .001 & .820 & 1.219 \\
\hline & $\mathrm{X} 2$ & .275 & .124 & .251 & 2.216 & .031 & .890 & 1.123 \\
\hline & $\mathrm{X} 3$ & .222 & .096 & .275 & 2.320 & .024 & .809 & 1.236 \\
\hline & $\mathrm{X} 4$ & .236 & .094 & .291 & 2.515 & .015 & .850 & 1.176 \\
\hline & $\mathrm{X} 5$ & .191 & .091 & .231 & 2.089 & .041 & .928 & 1.078 \\
\hline \multicolumn{3}{|c|}{$\begin{array}{l}\mathrm{R}=0,621 \\
\mathrm{R} \text { Square }=0,385 \\
\text { Adj. } \mathrm{RS} \text { Square }=0,328\end{array}$} & \multicolumn{2}{|c|}{$\begin{array}{l}\text { Fhitung }=6.736 \\
\text { Sig. F =0,000 } \\
\alpha=0,05\end{array}$} & & & & \\
\hline
\end{tabular}

Model persamaan regresi yang dapat dituliskan dari hasil tersebut dalam bentuk persamaan regresi sebagai berikut:

$$
\mathrm{Y}=4,313+0,343 \mathrm{X}_{1}+0,275 \mathrm{X}_{2}+0,222 \mathrm{X}_{3}+0,236 \mathrm{X}_{4}+0,191 \mathrm{X}_{5}
$$

Berdasarkan persamaan regresi linear berganda di atas, dapat dijelaskan bahwa variabel factor pribadi (Usia dan siklus hidup, pekerjaan, keadaan ekonomi, gaya hidup, serta kepribadian dan konsep diri) sebagai berikut:

1. Nilai konstanta sebesar 4,313\% memberi pengertian bahwa jika variabel independen dianggap 0 , maka kepuasan konsumen menggunakan Handphone Merek Samsung di Kota Palu adalah 4,313\%

2. Koefisien regresi variabel usia dan tahap siklus hidup mempunyai arah positif maknanya apabila Usia dan Tahap siklus hidup meningkat, maka kepuasan konsumen menggunakan Handphone Samsung di Kota Palu meningkat sebesar 34,3\%

3. Koefisien regresi variabel pekerjaan mempunyai arah positif maknanya apabila Pekerjaan meningkat, maka kepuasan konsumen menggunakan Handphone Samsung di Kota Palu meningkat sebesar $27,5 \%$

4. Koefisien regresi variabel keadaan ekonomi mempunyai arah positif maknanya apabila keadaan ekonomi meningkat kepuasan konsumen menggunakan Handphone Samsung di Kota Palu meningkat sebesar $22,2 \%$

5. Koefisien regresi variable Gaya Hidup mempunyai arah positif maknanya apabila gaya hidup meningkat kepuasan konsumen menggunakan Handphone Samsung di Kota Palu meningkat sebesar $23,6 \%$

6. Koefisien regresi variabel Kepribadian dan Konsep Diri mempunyai arah positif maknanya apabila kepribadian dan konsep diri meningkat kepuasan konsumen menggunakan Handphone Samsung di Kota Palu meningkat sebesar 19,1\%

7. Hasil analisis sebagaimana ditunjukkan pada tabel 4 membuktikan bahwa nilai koefisien determinasi adalah sebesar 0,385. Nilai ini memberi arti bahwa jika terjadi perubahan terhadap faktor pribadi, maka kepuasan konsumen menggunakan Handphone Merek Samsung di Kota Palu akan mengalami perubahan. Dengan kata lain kontribusi dari variabel bebas mampu mempengaruhi variasi perubahan variabel terikat adalah sebesar 38,5\% 
8. Nilai koefisien korelasi menunjukkan tingkat keeratan antara rintangan pengalihan dan penanganan keluhan dengan faktor kepuasan konsumen menggunakan Handphone Merek Samsung di Kota Palu. Hasil perhitungan sebagaimana ditunjukkan pada tabel 4 membuktikan bahwa nilai koefisien korelasi adalah sebesar 0,621. Nilai ini memberikan arti bahwa antara faktor pribadi dengan kepuasan konsumen membeli Handphone Merek Samsung di Kota Palu terdapat hubungan sebesar $62,1 \%$. Kuat tidaknya hubungan tersebut, peneliti merujuk pada pernyataan Sugiyono (2002), yang berarti hubungan tersebut kuat, karena nilai 0,621 berada diantara nilai 0,60-0,799. Dengan demikian maka antara rintangan pengalihan dan penanganan keluhan dengan faktor kepuasan konsumen menggunakan Handphone Merek Samsung di Kota Palu terdapat hubungan yang kuat.

\section{Pengujian Hipotesis}

\section{Pengujian Hipotesis Pertama (Uji Serempak / Uji F)}

Pengujian hipotesis pertama yaitu untuk mengetahui apakah variabel Usia, Pekerjaan, Keadaan Ekonomi, Gaya Hidup, dan Kepribadian dan Konsep Diri secara serempak berpengaruh positif dan signifikan terhadap kepuasan konsumen menggunakan Handphone Samsung di Kota Palu. Untuk lebih jelasnya dapat dilihat pada Tabel berikut ini:

\section{Tabel 5. Hasil Uji F}

\begin{tabular}{|c|c|c|c|c|c|c|c|c|c|c|}
\hline \multicolumn{11}{|c|}{ Model Summary } \\
\hline \multirow[b]{2}{*}{ Model } & \multirow[b]{2}{*}{$\mathrm{R}$} & \multirow[b]{2}{*}{ R Square } & \multirow[b]{2}{*}{ Adjusted R Square } & \multirow{2}{*}{$\begin{array}{l}\text { Std. Emor of the } \\
\text { Estimate }\end{array}$} & \multicolumn{5}{|c|}{ Change Statistics } & \multirow[b]{2}{*}{ Durbin-Watson } \\
\hline & & & & & R Square Change & F Change & df1 & $\mathrm{df2}$ & Siq. F Change & \\
\hline 1 & $.621^{13}$ & .385 & .328 & .51079 & .385 & 6.763 & 5 & 54 & .000 & 1.644 \\
\hline
\end{tabular}

a. Predictors: (Constant), X5, X1, X4, X2, X3

b. Dependent Variable: $Y$

Permasalahan pertama dalam penelitian ini diajukan pertanyaan apakah factor pribadi berpengaruh secara serempak terhadap kepuasan konsumen membeli Handphone Merek Samsung di Kota Palu. Untuk menjawab permasalahan pertama dilakukan pendekatan uji-F, dimana uji-F berguna untuk mendeteksi apakah kelima faktor bebas memiliki pengaruh secara serempak terhadap kepuasan konsumen menggunakan Handphone Merek Samsung di Kota Palu.

Berdasarkan hasil perhitungan regresi linier berganda, sebagaimana ditunjukkan pada tabel 4 di atas, diketahui bahwa nilai F-hitung sebesar 6.763 dan nilai signifikansi sebesar 0.000. Dalam kaidah pengambilan dinyatakan bahwa jika nilai signifikansi $\mathrm{F}<\alpha=0,05$, maka secara serempak rintangan pengalihan dan penanganan keluhan berpengaruh terhadap kepuasan konsumen membeli Handphone Merek Samsung di Kota Palu. Dengan demikian maka hipotesis penelitian yang pertama diterima.

Hasil pemaparan secara serempak di atas, dapat disimpulkan bahwa faktor pribadi secara serempak berpengaruh signifikan terhadap kepuasan konsumen membeli Handphone Merek Samsung di Kota Palu. Dengan demikian hipotesis pertama yang diajukan dalam penelitian ini terbukti kebenarannya, atau dengan kata lain hipotesis mula-mula (H0) ditolak dan menerima hipotesis alternatif (H1).

\section{Uji t (Pengujian hipotesis secara parsial)}

Untuk menguji keberartian model regresi untuk masing-masing variabel secara parsial dapat diperoleh dengan menggunakan uji t. Berikut akan dijelaskan pengujian masing-masing variabel secara parsial.

\section{Variabel Usia dan Tahap Siklus Hidup $\left(X_{I}\right)$}

Hasil pengujian diperoleh nilai t sig $0,001<0,05$. Dengan nilai signifikansi di bawah 0,05 tersebut menunjukkan bahwa usia dan tahap siklus hidup memiliki pengaruh yang signifikan terhadap kepuasan. Hal ini berarti Hipotesis 1 diterima. Arah koefisien regresi positif berarti bahwa bukti fisik memiliki pengaruh positif yang signifikan terhadap kepuasan konsumen menggunakan handphone Samsung di Kota Palu. 


\section{Variabel Pekerjaan $\left(\mathrm{X}_{2}\right)$}

Hasil pengujian diperoleh nilai t untuk variabel pekerjaan menunjukkan nilai $t=2,216$ dengan nilai signifikansi sebesar $0,031<0,05$. Dengan nilai signifikansi di bawah 0,05 tersebut menunjukkan bahwa pekerjaan memiliki pengaruh yang signifikan terhadap kepuasan konsumen. Hal ini berarti Hipotesis 2 diterima. Arah koefisien regresi positif berarti bahwa pekerjaan memiliki pengaruh positif yang signifikan terhadap kepuasan konsumen. Semakin baik pekerjaan yang diberikan akan semakin tinggi pula kepuasan konsumen, sebaliknya semakin rendah pekerjaan pelayanan yang diberikan semakin rendah pula kepuasan konsumen.

\section{Variabel Keadaan Ekonomi $\left(X_{3}\right)$}

Hasil pengujian diperoleh nilai $t$ untuk variabel keadaan ekonomi menunjukkan nilai $t=2,320$ dengan nilai signifikansi sebesar $0,024<0,05$. Dengan nilai signifikansi di bawah 0,05 tersebut menunjukkan bahwa keadaan ekonomi memiliki pengaruh yang signifikan terhadap kepuasan konsumen. Hal ini berarti Hipotesis 3 diterima. Arah koefisien regresi positif berarti bahwa Keadaan Ekonomi memiliki pengaruh positif yang signifikan terhadap kepuasan konsumen. Semakin tinggi keadaan ekonomi yang ada dalam perusahaan akan semakin tinggi pula kepuasan konsumen, sebaliknya semakin rendah keadaan ekonomi yang ada dalam perusahaan semakin rendah pula kepuasan konsumen.

\section{Variabel Gaya Hidup $\left(X_{4}\right)$}

Hasil pengujian diperoleh nilai $t$ untuk variabel gaya hidup menunjukkan nilai $t=2,515$ dengan nilai signifikansi sebesar $0,015<0,05$. Dengan nilai signifikansi di bawah 0,05 tersebut menunjukkan bahwa gaya hidup memiliki pengaruh yang signifikan terhadap kepuasan konsumen. Hal ini berarti Hipotesis 4 diterima. Arah koefisien regresi positif berarti bahwa gaya hidup memiliki pengaruh positif yang signifikan terhadap kepuasan konsumen. Semakin besar gaya hidup yang diberikan perusahaan akan semakin tinggi pula kepuasan konsumen, sebaliknya semakin rendah gaya hidup yang diberikan perusahaan semakin rendah pula kepuasan konsumen.

\section{Variabel Kepribadian dan Konsep Diri $\left(X_{5}\right)$}

Hasil pengujian diperoleh nilai $\mathrm{t}$ untuk variabel kepribadian dan konsep diri menunjukkan nilai $\mathrm{t}=$ 2,089 dengan nilai signifikansi sebesar $0,041<0,05$. Dengan nilai signifikansi di bawah 0,05 tersebut menunjukkan bahwa kepribadian dan konsep diri memiliki pengaruh yang signifikan terhadap kepuasan konsumen.

Hal ini berarti Hipotesis 5 diterima. Arah koefisien regresi positif berarti bahwa empati memiliki pengaruh positif yang signifikan terhadap kepuasan konsumen. Semakin besar kepribadian dan konsep diri yang diberikan perusahaan akan semakin tinggi pula kepuasan konsumen, sebaliknya semakin rendah kepribadian dan konsep diri yang diberikan perusahaan semakin rendah pula kepuasan konsumen.

\section{PEMBAHASAN HASIL PENELITIAN}

\section{Pengaruh Variabel Usia dan Tahap Siklus Hidup $\left(X_{I}\right)$}

Konsumsi juga dibentuk oleh siklus hidup keluarga dan jumlah, usia, serta jenis kelamin orang dalam rumah tangga pada satu waktu tertentu. Pemasar juga harus memperhitungkan kejadian atau transisi hidup yang penting- Pernikahan, kelahiran, sakit, pindah tempat, perceraian, perubahan karier, menjadi janda- akan memunculkan kebutuhan baru .Hasil yang diperoleh pada penelitian ini diperoleh bahwa besarnya nilai t sig 0,001 $<0,05$ dengan demikian bahwa secara statistik usia dan tahap siklus hidup berpengaruh secara signifikan terhadap variabel dependen (kepuasan konsumen) menggunakan Handphone merek Samsung di Kota Palu.

Hasil penelitian juga terlihat bahwa pengaruh positif antara usia dan tahap siklus hidup terhadap kepuasan konsumen, yang berarti semakin meningkat usia dan tahap siklus hidup masyarakat kota palu, maka semakin meningkat kepuasan konsumen menggunakan handphone merek Samsung di Kota Palu. Henni Noviasari dan Muhammad Aulia Ikram (2013) mengadakan penelitian dengan judul "Pengaruh Faktor Sosial dan Faktor Pribadi Terhadap Kepuasan konsumen Pembelian Kamera DSLR Canon Di Kota Pekanbaru" Penelitian ini dilakukan di Kota Pekanbaru yang menyatakan bahwa usia dan tahap siklus hidup berpengaruh signifikan terhadap kepuasan konsumen membeli kamera DSLR Canon di Kota Pekanbaru. 


\section{Pengaruh Variabel Pekerjaan $\left(X_{2}\right)$}

Pekerjaan juga mempengaruhi pola konsumsi. Pekerja kerah biru akan membeli baju kerja, sepatu kerja, dan kotak makan. Presiden perusahaan akan membeli jas, perjalanan jalan, dan keaggotaan country club. Pemasar mengidentifikasi kelompok pekerjaan yang mempunyai minat di atas rata-rata terhadap produk dan jasa mereka dan bahkan menghantarkan produk khusus untuk kelompok pekerjaan tertentu: Perusahaan piranti lunak komputer, misalnya, merancang beragam produk untuk manajer produk merek, insinyur, pengacara, dan dokter.

Hasil yang diperoleh pada penelitian ini diperoleh bahwa besarnya nilai t sig $0,031<0,05$ dengan demikian bahwa secara statistik pekerjaan berpengaruh secara signifikan terhadap variabel dependen (kepuasan konsumen) membeli Handphone merek Samsung di Kota Palu. Hal tersebut juga menjelaskan bahwa pekerjaan berpengaruh positif terhadap kepusan konsumen, yang artinya bahwa jika pekerjaan lebih baik maka akan meningkatkan kepuasan konsumen membeli handphone merek Samsung di Kota Palu.

Hal tersebut sesuai dengan penelitian yang dilakukan oleh Ainun Jariah (2012) mengadakan penelitian dengan judul "Analisis faktor-faktor pribadi yang mempengaruhi keputusan pembelian sepeda motor Yamaha di lumajang". Dengan hasil penelitian bahwa pekerjaan secara parsial berpengaruh terhadap keputusan pembelian sepeda motor Yamaha di Lumajang.

\section{Pengaruh Variabel Keadaan Ekonomi $\left(X_{3}\right)$}

Pilihan produk sangat dipengaruhi oleh keadaan ekonomi: penghasilkan yang dibelanjakan (tingkat, stabilitas, dan pola waktu), tabungan dan aset (termasuk presentase aset likuid), utang, kekuatan pinjaman, dan sikap terhadap pengeluaran dan tabungan. Pembuat barang mewah seperti Gucci, Prada, dan Burberry rentan terhadap penurunan ekonomi. Hasil yang diperoleh pada penelitian ini bahwa besarnya nilai t sig 0,024 $<0,05$ dengan demikian bahwa secara statistik keadaan ekonomi berpengaruh secara signifikan terhadap variabel dependen (kepuasan konsumen) membeli handphone merek samsung di Kota palu. Hal tersebut sesuai dengan penelitian yang dilakukan oleh Ainun Jariah (2012) mengadakan penelitian dengan judul "Analisis faktor-faktor pribadi yang mempengaruhi keputusan pembelian sepeda motor Yamaha di lumajang". Dengan hasil penelitian bahwa keadaan ekonomi secara parsial berpengaruh terhadap keputusan pembelian sepeda motor Yamaha di Lumajang.

\section{Pengaruh Variabel Gaya Hidup $\left(\mathrm{X}_{4}\right)$}

Gaya hidup (lifestyle) adalah pola hidup seseorang di dunia yang tercermin dalam kegiatan, minat, dan pendapat. Gaya hidup memotret interaksi "seseorang secara utuh" dengan lingkungannya. Pemasar meneliti hubungan antara produk mereka dan kelompok gaya hidup.

Hasil yang diperoleh pada penelitian ini diperoleh bahwa besarnya nilai t sig 0,015 $<0,05$ dengan demikian bahwa secara statistik gaya hidup berpengaruh secara signifikan terhadap variabel dependen (kepuasan konsumen) menggunakan Handphone merek Samsung di Kota Palu. Hal tersebut juga menjelaskan bahwa gaya hidup berpengaruh positif terhadap kepusan konsumen, yang artinya bahwa jika gaya hidup lebih baik maka akan meningkatkan kepuasan konsumen menggunakan handphone merek Samsung di Kota Palu.

Hal tersebut sesuai dengan penelitian yang dilakukan oleh Ainun Jariah (2012) mengadakan penelitian dengan judul "Analisis faktor-faktor pribadi yang mempengaruhi keputusan pembelian sepeda motor Yamaha di lumajang". Dengan hasil penelitian bahwa gaya hidup secara parsial berpengaruh terhadap keputusan pembelian sepeda motor Yamaha di Lumajang.

\section{Pengaruh Variabel Kepribadian dan Konsep Diri $\left(X_{5}\right)$}

Setiap orang mempunyai karakteristik pribadi yang mempengaruhi perilaku pembeliannya. Yang dimaksudkan dengan kepribadian (personality), adalah sekelompokan sifat psikologi manusia yang 
menyebabkan respons yang relative konsisten dan tahan lama terhadap rangsangan lingkungan (termasuk perilaku pembelian).

Hasil yang diperoleh pada penelitian ini diperoleh bahwa besarnya nilai t sig 0,041 $<0,05$ dengan demikian bahwa secara statistik kepribadian dan konsep diri berpengaruh secara signifikan terhadap variabel dependen (kepuasan konsumen) menggunakan Handphone merek Samsung di Kota Palu. Hal tersebut juga menjelaskan bahwa kepribadian dan konsep diri berpengaruh positif terhadap kepusan konsumen, yang artinya bahwa jika kepribadian dan konsep diri lebih baik maka akan meningkatkan kepuasan konsumen menggunakan handphone merek Samsung di Kota Palu. Hal tersebut sesuai dengan penelitian yang dilakukan oleh Cindy Liffie Maleke (2013) mengadakan penelitian dengan judul "Faktor Sosal, Pribadi, dan Psikologis Pengaruhnya Terhadap Keputusan Pembelian Blackberry Gemini pada PT. Mega Mitra Sejahtera" dengan hasil penelitian bahwa kepribadian dan konsep diri secara parsial berpengaruh terhadap keputusan pembelian blackberry Gemini pada PT. Mega Mitra Makmur Sejahtera.

\section{KESIMPULAN DAN SARAN}

\section{Kesimpulan}

1. Variabel Faktor Pribadi secara simultan memberikan pengaruh positif terhadap kepuasan konsumen Membeli Handphone merek Samsung di Kota Palu

2. Variabel Usia dan Tahap Siklus Hidup (X1) secara parsial memberikan pengaruh positif terhadap kepuasan konsumen Membeli Handphone merek Samsung di Kota Palu

3. Variabel Pekerjaan (X2) secara parsial memberikan pengaruh positif terhadap kepuasan konsumen Membeli Handphone merek Samsung di Kota Palu

4. Variabel Keadaan Ekonomi (X3) secara parsial memberikan pengaruh positif terhadap kepuasan konsumen Membeli Handphone merek Samsung di Kota Palu

5. Variabel Gaya Hidup (X4) secara parsial memberikan pengaruh positif terhadap kepuasan konsumen Membeli Handphone merek Samsung di Kota Palu

6. Variabel kepribadian dan konsep diri (X5) secara parsial memberikan pengaruh positif terhadap kepuasan konsumen Membeli Handphone merek Samsung di Kota Palu

\section{Saran}

1. Kepada pihak Handphone merek Samsung, Untuk meningkatkan ketertarikan menggunakan smartphone merek Samsung maka sebaiknya berbagai fitur atau layanan smartphone merek Samsung terus dilakukan peningkatan sehingga bisa memberikan daya tarik bagi konsumen untuk menggunakan smartphone merek Samsung

2. Untuk penelitian selanjutnya, diharapkan untuk mencari, menambahkan, atau bahkan mengkombinasikan variabel-variabel pembentuk kepuasan pembelian Handphone merek Samsung, agar hasil penelitiannya memberikan kontribusi yang bermakna pada pihak-pihak yang berkepentingan.

\section{REFERENSI}

Jariah Ainun (2012) Analisis faktor-faktor pribadi yang mempengaruhi keputusan pembelian sepeda motor Yamaha di lumajang, Jurnal WIGA Vol. 2 No. 2, September 2012 ISSN NO 2088-0944

Kotler, P. \& Keller, K. L. (2009). Manajemen Pemasaran (13 ${ }^{\text {th }}$ ed. 1). Jakarta: Erlangga.

Kotler, P. \& Amstrong, G. (2008). Prinsip-prinsip Pemasaran (12th ed.1). Jakarta: Erlangga.

Noviasari Henni dan Aulia Muhammad Ikram (2013) Pengaruh Faktor Sosial dan Faktor Pribadi

Terhadap Keputusan Konsumen Pembelian Kamera DSLR Canon Di Kota Pekanbaru, Jurnal

Sosial Ekonomi Pembangunan Tahun III No. 9, Juli 2013 : 253-267, ISSN : 2087-4502

Simamora, H. (2000). Manajemen Pemasaran Internasional. Jilid kedua. Jakarta: Salemba Empat

Sugiyono. (2002) Metode Penelitian Administrasi. Bandung : CV Alfabeta

Sugiyono. (2013). Statistika untuk Penelitian. Bandung: Alfabeta

Sugiyono. (2014). Memahami Penelitian Kualitatif. Bandung: AlfaBeta 